\title{
A Global Overview of COVID-19 Research in the Pediatric Field: Bibliometric Review
}

Alice Monzani ${ }^{1}, \mathrm{MD}, \mathrm{PhD}$; Francesco Tagliaferri ${ }^{1}, \mathrm{MD}$; Simonetta Bellone ${ }^{1}$, Prof Dr; Giulia Genoni ${ }^{2}, \mathrm{MD}, \mathrm{PhD}$; Ivana Rabbone ${ }^{1}$, Prof Dr

${ }^{1}$ Division of Pediatrics, Department of Health Sciences, Università del Piemonte Orientale, Novara, Italy

${ }^{2}$ Pediatric and Neonatal Intensive Care Unit, Maggiore della Carità University Hospital, Novara, Italy

Corresponding Author:

Alice Monzani, MD, PhD

Division of Pediatrics

Department of Health Sciences

Università del Piemonte Orientale

Via Solaroli 17

Novara, 28100

Italy

Phone: 3903213733868

Fax: 3903213733598

Email: alice.monzani@med.uniupo.it

\section{Abstract}

Background: Since the beginning of the COVID-19 pandemic, a great number of papers have been published in the pediatric field.

Objective: We aimed to assess research around the globe on COVID-19 in the pediatric field by bibliometric analysis, identifying publication trends and topic dissemination and showing the relevance of publishing authors, institutions, and countries.

Methods: The Scopus database was comprehensively searched for all indexed documents published between January 1, 2020, and June 11, 2020, dealing with COVID-19 in the pediatric population (0-18 years). A machine learning bibliometric methodology was applied to evaluate the total number of papers and citations, journal and publication types, the top productive institutions and countries and their scientific collaboration, and core keywords.

Results: A total of 2301 papers were retrieved, with an average of 4.8 citations per article. Of this, 1078 (46.9\%) were research articles, $436(18.9 \%)$ were reviews, 363 (15.8\%) were letters, $186(8.1 \%)$ were editorials, $7(0.3 \%)$ were conference papers, and $231(10 \%)$ were categorized as others. The studies were published in 969 different journals, headed by The Lancet. The retrieved papers were published by a total of 12,657 authors from 114 countries. The most productive countries were the United States, China, and Italy. The four main clusters of keywords were pathogenesis and clinical characteristics (keyword occurrences: $\mathrm{n}=2240)$, public health issues $(\mathrm{n}=352)$, mental health $(\mathrm{n}=82)$, and therapeutic aspects $(\mathrm{n}=70)$.

Conclusions: In the pediatric field, a large number of articles were published within a limited period on COVID-19, testifying to the rush to spread new findings on the topic in a timely manner. The leading authors, countries, and institutions evidently belonged to the most impacted geographical areas. A focus on the pediatric population was often included in general articles, and pediatric research about COVID-19 mainly focused on the clinical features, public health issues, and psychological impact of the disease.

(JMIR Pediatr Parent 2021;4(3):e24791) doi: 10.2196/24791

\section{KEYWORDS}

COVID-19; SARS-CoV-2; children; pediatrics; bibliometric review; publications; research; literature; review

\section{Introduction}

With its massive and rapid spread, the COVID-19 pandemic has been an unprecedented challenge for health care systems worldwide [1]. At the same rate, the research community has been extremely prolific, with a considerable amount of scientific papers published within a very short time, in an effort to address all aspects of disease management in a timely manner. Many 
journals are offering fast-track publication for COVID-19-related papers. The availability of reviewers for an expedited review process has been called for. In other words, the editorial process that usually characterizes the research on a disease has been sped up and amplified in this exceptional circumstance.

Infection by SARS-CoV-2 seems to be milder in the pediatric population than in the elderly [2], and the relative protection of children against the severe forms of COVID-19 is a major point of interest in the comprehension of the pathogenetic mechanisms of the disease [3]. Therefore, research on COVID-19 in the pediatric field has experienced a strong increase. The very high number of continuously published papers and the speed at which research on this topic has been generated makes it extremely difficult to stay updated with such a rapidly evolving knowledge base. In this regard, a bibliometric analysis of the current literature on pediatric COVID-19 can help clinicians stay updated with emerging and swiftly evolving scientific outcomes. Bibliometric analysis is the attempt to quantitatively assess the current literature on a certain topic, allowing researchers to acquire knowledge about research trends and providing insights into the contribution of a particular country or institution to that topic, as well as data on coauthorship and collaboration [4].

Therefore, we performed a bibliometric analysis of the papers on COVID-19 in the pediatric field published in the first half of 2020 to assess research on this topic on a global scale, identify publication trends, and provide some hints on the gap of knowledge to be filled by future research.

\section{Methods}

The Scopus database was comprehensively searched for all the indexed documents published between January 1, 2020, and June 11, 2020, dealing with COVID-19 in the pediatric population ( $0-18$ years of age). The keywords used were COVID or coronavirus and pediatric or child or children or adolescent $\$$ in the title or abstract. We used only these terms to conduct a broad search that would ensure the inclusion of relevant literature. The inclusion criteria were papers that (1) were published after the first report of COVID-19 from the Wuhan government on December 31, 2019, and (2) matched the search keywords. As COVID-19 was first reported in China and a fairly large number of research papers were written in Chinese, language was not limited during the retrieval process.

The literature retrieval group consisted of 3 trained professionals. We used the export feature of the search engine to retrieve data for further processing. All extracted literature entries were exported into Microsoft Excel (Microsoft Corp) for screening and selection. The reviewers (AM, FT, GG, SB) independently screened the titles, abstracts, and, if ambiguous, full texts for the inclusion of articles. Discrepancies were resolved through discussions among them and with a fifth reviewer (IR) in case of difficulties in reaching an agreement. The reviewers independently conducted information extraction from the included papers. Discrepancies were similarly resolved through discussion among the reviewers.

For studies that fulfilled the inclusion criteria, the following information was extracted: authors, affiliations, and country of origin (when there was more than one author, the corresponding author's information was used), journal, publication date, publication type, citation, and abstract. The abstract and title of every record retrieved were screened to determine which studies should be assessed further.

We performed explorative data analysis for:

- Total number of papers to measure global productivity;

- Total citations to assess the relevance of an author, institution, or country;

- Journal and publication types to assess topic dissemination;

- Scientific collaboration between authors, institutions, and countries to show how they related to others;

- Core keywords to show clusters of research topics.

The intracountry and intercountry collaboration indices were presented as single-country publication (SCP) and multiple-country publication (MCP), according to the country of the corresponding author, and the timing of the first COVID-19 case reported for each country was highlighted as well.

A machine learning bibliometric methodology was applied to evaluate the distribution of each factor. The bibliometrix $\mathrm{R}$ package with its Biblioshiny web interface was used [5].

No ethics approvals were considered necessary as this was a literature-based study.

\section{Results}

\section{General Data}

A total of 2301 papers were retrieved. Out of them, 1078 $(46.9 \%)$ were research articles, $436(18.9 \%)$ were reviews, 363 $(15.8 \%)$ were letters, $186(8.1 \%)$ were editorials, $7(0.3 \%)$ were conference papers, and $231(10 \%)$ were categorized as others.

\section{Citation Analysis}

The retrieved articles had 11,063 citations with an average of 4.8 citations per article. Of the retrieved papers, 869 (37.8\%) were cited at least once. The 10 most frequently cited articles are shown in Table 1 . The top-ranking paper ( $\mathrm{n}=1255$ citations) was published in The New England Journal of Medicine and was focused on the clinical characteristics of COVID-19 in China.

Table 2 shows the distribution of the prevalence of the retrieved articles according to the number of citations. 
Table 1. List of the 10 most cited articles about COVID-19 in the pediatric population.

\begin{tabular}{|c|c|c|c|c|}
\hline Authors and reference & Title & Journal & Publication date & Total citations, $\mathrm{n}(\%)$ \\
\hline Guan et al [6] & $\begin{array}{l}\text { Clinical characteristics of coronavirus dis- } \\
\text { ease } 2019 \text { in China }\end{array}$ & $\begin{array}{l}\text { The New England Journal of } \\
\text { Medicine }\end{array}$ & April 30, 2020 & $1255(11.3)$ \\
\hline Chan et al [7] & $\begin{array}{l}\text { A familial cluster of pneumonia associated } \\
\text { with the } 2019 \text { novel coronavirus indicating } \\
\text { person-to-person transmission: A study of } \\
\text { a family cluster }\end{array}$ & Lancet & February 15,2020 & $735(6.6)$ \\
\hline Mehta et al [8] & $\begin{array}{l}\text { COVID-19: Consider cytokine storm syn- } \\
\text { dromes and immunosuppression }\end{array}$ & Lancet & March 13, 2020 & $324(2.9)$ \\
\hline Wu et al [9] & $\begin{array}{l}\text { A new coronavirus associated with human } \\
\text { respiratory disease in China }\end{array}$ & Nature & February 3, 2020 & $309(2.8)$ \\
\hline Wu et al [10] & $\begin{array}{l}\text { Risk factors associated with acute respirato- } \\
\text { ry distress syndrome and death in patients } \\
\text { with coronavirus disease } 2019 \text { pneumonia } \\
\text { in Wuhan, China }\end{array}$ & JAMA Internal Medicine & March 13, 2020 & $291(2.6)$ \\
\hline Chen et al [11] & $\begin{array}{l}\text { Clinical characteristics and intrauterine } \\
\text { vertical transmission potential of COVID- } \\
19 \text { infection in nine pregnant women: A } \\
\text { retrospective review of medical records }\end{array}$ & Lancet & February 12,2020 & $275(2.5)$ \\
\hline Lai et al [12] & $\begin{array}{l}\text { Severe acute respiratory syndrome coron- } \\
\text { avirus } 2 \text { (SARS-CoV-2) and coronavirus } \\
\text { disease-2019 (COVID-19): The epidemic } \\
\text { and the challenges }\end{array}$ & $\begin{array}{l}\text { International Journal of Antimi- } \\
\text { crobial Agents }\end{array}$ & February 12,2020 & $213(1.9)$ \\
\hline Xu et al [13] & $\begin{array}{l}\text { Evolution of the novel coronavirus from the } \\
\text { ongoing Wuhan outbreak and modeling of } \\
\text { its spike protein for risk of human transmis- } \\
\text { sion }\end{array}$ & Science China Life Sciences & January 21,2020 & $153(1.4)$ \\
\hline Dong et al [14] & $\begin{array}{l}\text { Epidemiology of COVID-19 among chil- } \\
\text { dren in China }\end{array}$ & Pediatrics & June 1,2020 & $134(1.2)$ \\
\hline Lu et al [15] & SARS-CoV-2 infection in children & $\begin{array}{l}\text { The New England Journal of } \\
\text { Medicine }\end{array}$ & April 23, 2020 & $128(1.2)$ \\
\hline
\end{tabular}

Table 2. Distribution of published papers about COVID-19 in the pediatric population according to the number of citations.

\begin{tabular}{ll}
\hline Number of citations & Articles, $\mathrm{n}(\%)$ \\
\hline$>100$ & $17(0.74)$ \\
$50-100$ & $25(1.09)$ \\
$20-49$ & $70(3.04)$ \\
$5-19$ & $202(8.78)$ \\
$<5$ & $1989(86.44)$ \\
\hline
\end{tabular}

\section{Journal Analysis}

The studies were published in 969 different journals. The Lancet headed the list with a total number of 29 publications, followed by the Journal of Medical Virology $(\mathrm{n}=26)$ and Science of the Total Environment $(\mathrm{n}=25)$. In analyzing the publications' reference lists, the most cited sources were The Lancet $(\mathrm{n}=2336$ citations), followed by The New England Journal of Medicine $(\mathrm{n}=1835)$, and the Journal of American Medical Association $(\mathrm{n}=1017)$.

\section{Author Analysis}

A total of 12,657 authors contributed to these papers, with a mean of 5.5 authors per document. Out of this total, 239 were authors of single-authored documents and 12,418 were authors of multiauthored documents.

\section{Country Analysis}

The retrieved papers were published by authors from 114 countries. The most productive country in the COVID-19 research field in pediatrics was the United States, with 178 publications, followed by China, with 138 publications, and Italy, with 87 publications. Table 3 shows the top 10 productive countries. 
Table 3. The top 10 productive countries publishing on the topic of COVID-19 in the pediatric population.

\begin{tabular}{lllll}
\hline Country & Articles, $\mathrm{n}$ & $\mathrm{SCP}^{\mathrm{a}}, \mathrm{n}$ & $\mathrm{MCP}^{\mathrm{b}}, \mathrm{n}$ & First reported case $^{\mathrm{c}}$ \\
\hline United States & 178 & 134 & 44 & January 30,2020 \\
China & 138 & 119 & 19 & December 31,2019 \\
Italy & 87 & 70 & 17 & February 20, 2020 \\
India & 30 & 23 & 7 & March 2, 2020 \\
France & 26 & 21 & 5 & February 7, 2020 \\
United Kingdom & 23 & 10 & 13 & January 28, 2020 \\
Canada & 22 & 10 & 12 & January 27, 2020 \\
Iran & 19 & 15 & 4 & February 19, 2020 \\
Korea & 18 & 14 & 4 & January 20, 2020 \\
Australia & 17 & 11 & 6 & January 25, 2020 \\
\hline
\end{tabular}

${ }^{\text {a }} \mathrm{SCP}$ : single-country publication.

${ }^{\mathrm{b}} \mathrm{MCP}$ : multiple-country publication.

${ }^{\mathrm{c}}$ Source: WHO Coronavirus (COVID-19) Dashboard [16].

\section{Institution Analysis}

The published articles came from 4919 institutions, with the top 10 institutions accounting for $614(26.7 \%)$ papers. The Huazhong University of Science and Technology was the most productive institution, with 117 documents, followed by Harvard Medical School ( $\mathrm{n}=82$ publications) and the University of Oxford $(n=67)$. Table 4 displays the top 10 productive institutions.

Table 4. The top 10 productive institutions publishing on the topic of COVID-19 in the pediatric population.

\begin{tabular}{lll}
\hline Institution & Country & Articles, $\mathrm{n}(\%)$ \\
\hline Huazhong University of Science and Technology & China & $117(5.1)$ \\
Harvard Medical School & United States & $82(3.6)$ \\
University of Oxford & United Kingdom & $67(2.9)$ \\
University of Washington & United States & $63(2.7)$ \\
University of California & United States & $61(2.6)$ \\
University of Toronto & Canada & $56(2.4)$ \\
Tehran University of Medical Sciences & Iran & $47(2.0)$ \\
University College London & United Kingdom & $45(2.0)$ \\
Universal Scientific Education and Research Network & - $^{\mathrm{a}}$ & $39(1.7)$ \\
University of Melbourne & Australia & $37(1.6)$ \\
\hline
\end{tabular}

${ }^{\mathrm{a}}$ Not applicable.

\section{Collaboration Analysis}

Figure 1 shows the country collaboration analysis. The network diagram showed that China and the United States were the leaders in COVID-19 research in cooperation with other countries (each node represents a country, node size corresponds to publication number, connecting lines represents country cooperation, and line thickness indicates collaboration frequencies). Overall, developed countries had greater collaboration networks than developing territories. 
Figure 1. Collaboration map between countries in publications on COVID-19 in the pediatric population.

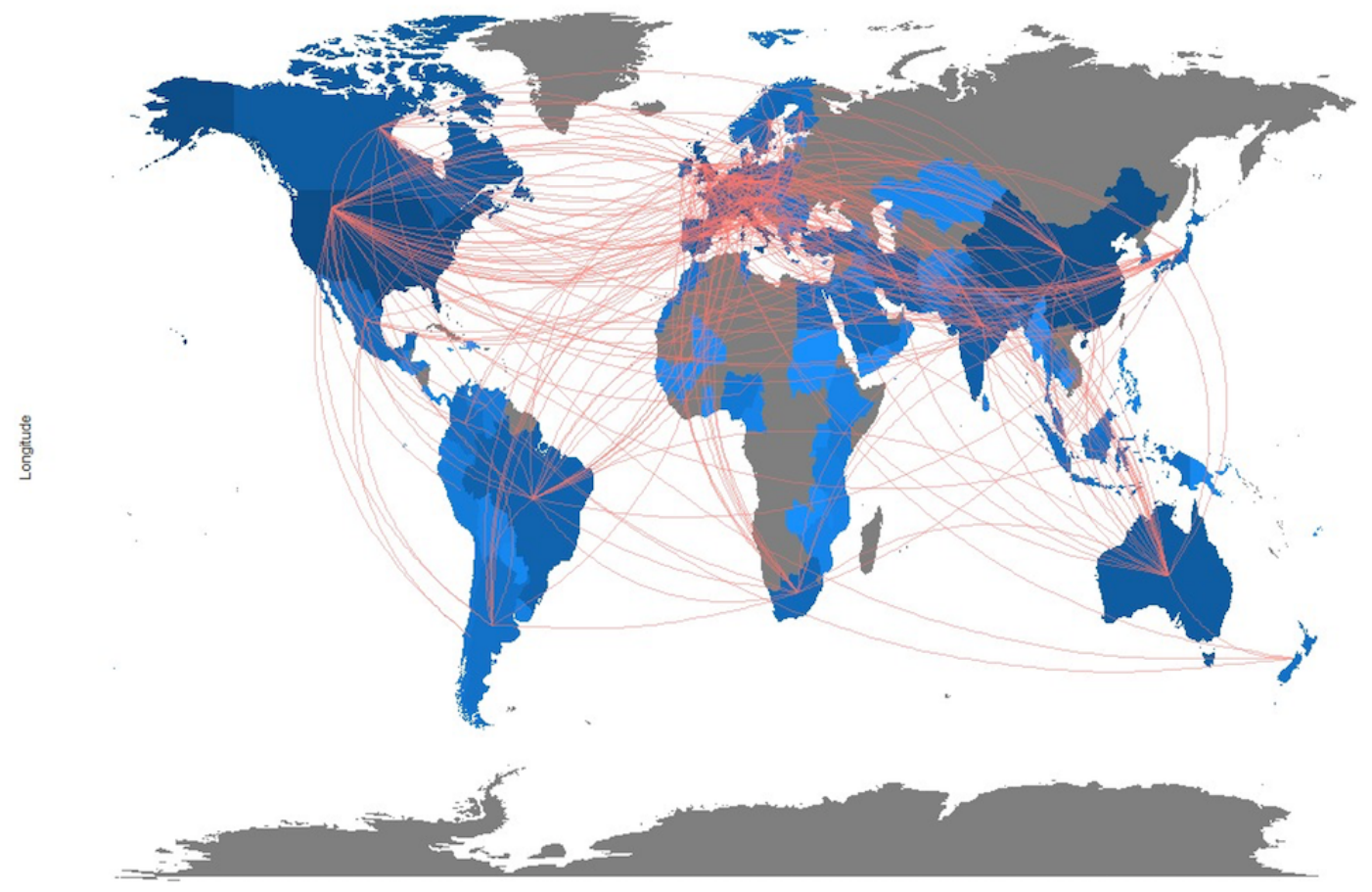

\section{Keyword Analysis}

Overall, the three most common keywords were COVID-19 with 880 occurrences, coronavirus with 368 occurrences and Sars-Cov 2 with 294 occurrences. Multimedia Appendix 1 shows a word cloud for the most common keywords of the retrieved papers

When keywords were clustered into themes, four main clusters emerged: pathogenesis and clinical characteristics (keyword occurrence: $n=2240)$, public health issues $(n=352)$, mental health $(n=82)$, and therapeutic aspects $(n=70)$.

\section{Discussion}

\section{Principal Findings}

In this bibliometric review, we aimed to provide a comprehensive portrait of published research on COVID-19 in the pediatric population. The bibliometric approach properly fits the aim of representing all scientific publications on a certain topic in a defined time frame. Therefore, this method has been recently used by many authors to depict the state of current knowledge about COVID-19 under different perspectives [17-27], and we used it to focus on the pediatric population.

The most impressive result was the large number of articles published within a limited period on a single topic. Most were research articles, but, notably, more than $15 \%$ of the total published papers were letters, testifying to the rush to quickly spread even preliminary results and personal perspectives [28]. The low rate of conference papers was probably due to the fact that most of the national and international conferences scheduled in that period were cancelled in compliance with social distancing measures.
The citation analysis showed that only about one-third of the published papers were cited at least once, suggesting that the short time frame and the rapidly increasing amount of literature likely lowered the possibility of a paper being cited. However, the top-cited paper reached a high number of citations in a very short time.

The leading authors, countries, and institutions evidently belonged to the most impacted geographical areas, as already pointed out in previous general bibliometric analyses.

The keyword analysis, as well as the top-cited articles, revealed that a focus on the pediatric population was often included in general articles about COVID-19 as well. Analyzing the keyword clusters, it was observed that pediatric research about COVID-19 mainly focused on the clinical features of the disease and public health issues. Notably, mental health-related topics were of outstanding interest, even overcoming therapeutic aspects. Psychosocial challenges and opportunities for children with chronic health conditions during lockdown, such as digital approaches to remote pediatric health care delivery, represented a mainstream topic in the publication trends during the pandemic $[29,30]$. This, along with the lack of emergency preparedness-related topics among the most recurrent keywords, could suggest that COVID-19 research in pediatrics more frequently addressed the psychological impact of lockdown, per the milder clinical course of the disease among children, and unlike what emerged in a similar bibliometric analysis outside the pediatric area [17].

Taken together, our findings demonstrate that scientists around the world, facing the unprecedented emergency of the COVID-19 pandemic, felt compelled to publish their findings and opinions with the aim to contribute to the evolving knowledge base as soon as new evidence emerged. This 
occurred even in the pediatric field, which has up to now not been so seriously involved in the COVID-19 emergency.

This process was facilitated by high-impact medical journals opening special issues or columns for COVID-19 [31], some publishers waiving publication fees and providing free access to article content, and many journals opting to fast track peer review. It would be desirable that some of these positive aspects implemented in the current difficult times would become common practice. Nonetheless, in such an accelerated publishing process, it should be of great importance to keep the quality of research papers high, which is essential to spread valuable information [22,32]. In the future, it would be interesting to compare this first 6-month publication rush to later publication attitudes about the COVID-19 topic in the pediatric field.

\section{Limitations}

Our study has some limitations that need to be acknowledged, pertaining mainly to the intrinsic bias of having considered only studies indexed in Scopus within a limited time frame, knowing that results may differ had other databases been included or the time period extended. However, this bibliometric analysis of COVID-19 publications in the pediatric field offers a global overview of what has been published on the topic, which allows for the identification of possible gaps in knowledge for new lines of research. In particular, the Scopus database was chosen for its reliability, wide coverage of scientific production, and daily updates. We decided to search only one database mainly to avoid duplicate results. Moreover, as this bibliometric analysis addressed a very recent and rapidly evolving topic, we preferred to search only one reliable database to overcome gaps in the promptness of updates from different sources. Finally, we preferred Scopus as our main data source since it provides data analysis for publications and citations, and allows the results to be sorted according to the number of citations.

Another limitation consists of the limited time frame of our analysis. Using a different methodological approach, such as a living systematic review, would allow for a real-time update on the rising evidence in such a rapidly evolving field. As a result, it would be possible for authors to constantly monitor gaps in knowledge, which they could try to fill with future research.

\section{Conclusion}

In conclusion, a substantial number of papers have been published on the topic of COVID-19 in the pediatric field. It would be advisable to carry on implementing the positive changes to publication policies that emerged during the COVID-19 pandemic, which will aid in providing solid evidence to inform and support clinical and public health decision making.

\section{Conflicts of Interest}

None declared.

\section{Multimedia Appendix 1}

Word cloud of the most frequently used keywords in papers about COVID-19 in the pediatric population. [PNG File, 926 KB-Multimedia Appendix 1]

\section{References}

1. WHO Health Emergency Dashboard. URL: https://extranet.who.int/publicemergency [accessed 2020-09-15]

2. De Luca CD, Esposito E, Cristiani L, Mancino E, Nenna R, Cortis E, et al. Covid-19 in children: A brief overview after three months experience. Paediatr Respir Rev 2020 Sep;35:9-14 [FREE Full text] [doi: 10.1016/j.prrv.2020.05.006] [Medline: $\underline{32593648]}$

3. Cristiani L, Mancino E, Matera L, Nenna R, Pierangeli A, Scagnolari C, et al. Will children reveal their secret? The coronavirus dilemma. Eur Respir J 2020 Apr 02;55(4):2000749 [FREE Full text] [doi: 10.1183/13993003.00749-2020] [Medline: 32241833 ]

4. Ellegaard O, Wallin J. The bibliometric analysis of scholarly production: How great is the impact? Scientometrics 2015;105(3):1809-1831 [FREE Full text] [doi: 10.1007/s11192-015-1645-z] [Medline: 26594073]

5. Aria M, Cuccurullo C. bibliometrix : An R-tool for comprehensive science mapping analysis. Journal of Informetrics 2017 Nov;11(4):959-975. [doi: 10.1016/i.joi.2017.08.007]

6. Guan WJ, Ni ZY, Hu Y, Liang WH, Ou CQ, He JX, China Medical Treatment Expert Group for Covid-19. Clinical Characteristics of Coronavirus Disease 2019 in China. N Engl J Med 2020 Apr 30;382(18):1708-1720 [FREE Full text] [doi: 10.1056/NEJMoa2002032] [Medline: 32109013]

7. Chan J, Yuan S, Kok K, To K, Chu H, Yang J, et al. A familial cluster of pneumonia associated with the 2019 novel coronavirus indicating person-to-person transmission: a study of a family cluster. The Lancet 2020 Feb;395(10223):514-523. [doi: 10.1016/S0140-6736(20)30154-9]

8. Mehta P, McAuley D, Brown M, Sanchez E, Tattersall R, Manson J. COVID-19: consider cytokine storm syndromes and immunosuppression. The Lancet 2020 Mar 03;395(10229):1033-1034. [doi: 10.1016/S0140-6736(20)30628-0]

9. Wu C, Zhao S, Yu B, Chen Y, Wang W, Song Z, et al. A new coronavirus associated with human respiratory disease in China. Nature 2020 Feb 03;579(7798):265-269 [FREE Full text] [doi: 10.1038/s41586-020-2008-3] [Medline: 32167524]

10. Wu C, Chen X, Cai Y, Xia J, Zhou X, Xu S, et al. Risk Factors Associated With Acute Respiratory Distress Syndrome and Death in Patients With Coronavirus Disease 2019 Pneumonia in Wuhan, China. JAMA Intern Med 2020 Jul 01;180(7):934-943 [FREE Full text] [doi: 10.1001/jamainternmed.2020.0994] [Medline: $\underline{32167524}$ ] 
11. Chen H, Guo J, Wang C, Luo F, Yu X, Zhang W, et al. Clinical characteristics and intrauterine vertical transmission potential of COVID-19 infection in nine pregnant women: a retrospective review of medical records. The Lancet 2020 Mar;395(10226):809-815 [FREE Full text] [doi: 10.1016/S0140-6736(20)30360-3] [Medline: 32081636]

12. Lai CC, Shih TP, Ko WC, Tang HJ, Hsueh PR. Severe acute respiratory syndrome coronavirus 2 (SARS-CoV-2) and coronavirus disease-2019 (COVID-19): The epidemic and the challenges. Int J Antimicrob Agents 2020 Mar 21;55(3):105924-105460 [FREE Full text] [doi: 10.1016/j.ijantimicag.2020.105924] [Medline: $\underline{32081636}$ ]

13. Xu X, Chen P, Wang J, Feng J, Zhou H, Li X, et al. Evolution of the novel coronavirus from the ongoing Wuhan outbreak and modeling of its spike protein for risk of human transmission. Sci China Life Sci 2020 Mar 16;63(3):457-460 [FREE Full text] [doi: $\underline{10.1007 / \mathrm{s} 11427-020-1637-5]}$ [Medline: $\underline{\text { 32009228] }}$

14. Dong Y, Mo X, Hu Y, Qi X, Jiang F, Jiang Z, et al. Epidemiology of COVID-19 Among Children in China. Pediatrics 2020 Jun 23;145(6):1663-1665 [FREE Full text] [doi: 10.1542/peds.2020-0702] [Medline: $\underline{32179660]}$

15. Lu X, Zhang L, Du H, Zhang J, Li YY, Qu J, Chinese Pediatric Novel Coronavirus Study Team. SARS-CoV-2 Infection in Children. N Engl J Med 2020 Apr 23;382(17):1663-1665 [FREE Full text] [doi: 10.1056/NEJMc2005073] [Medline: 32187458]

16. WHO Coronavirus (COVID-19) Dashboard. URL: https://covid19.who.int/ [accessed 2021-07-12]

17. Yu Y, Li Y, Zhang Z, Gu Z, Zhong H, Zha Q, et al. A bibliometric analysis using VOSviewer of publications on COVID-19. Ann Transl Med 2020 Jul;8(13):816-816 [FREE Full text] [doi: 10.21037/atm-20-4235] [Medline: 32793661]

18. Şenel E, Topal F. Holistic Analysis of Coronavirus Literature: A Scientometric Study of the Global Publications Relevant to SARS-CoV-2 (COVID-19), MERS-CoV (MERS) and SARS-CoV (SARS). Disaster Med Public Health Prep 2020 Aug 13:1-8 [FREE Full text] [doi: 10.1017/dmp.2020.300] [Medline: $\underline{32787980]}$

19. Odone A, Salvati S, Bellini L, Bucci D, Capraro M, Gaetti G, et al. The runaway science: a bibliometric analysis of the COVID-19 scientific literature. Acta Biomed 2020 Jul 20;91(9-S):34-39 [FREE Full text] [doi: 10.23750/abm.v91i9-S.10121] [Medline: 32701915]

20. Patil S. Indian Publications on SARS-CoV-2: A bibliometric study of WHO COVID-19 database. Diabetes Metab Syndr 2020;14(5):1171-1178 [FREE Full text] [doi: 10.1016/j.dsx.2020.07.007] [Medline: 32673837]

21. Liu N, Chee M, Niu C, Pek P, Siddiqui F, Ansah J, et al. Coronavirus disease 2019 (COVID-19): an evidence map of medical literature. BMC Med Res Methodol 2020 Jul 02;20(1):177 [FREE Full text] [doi: 10.1186/s12874-020-01059-y] [Medline: 32615936]

22. Nowakowska J, Sobocińska J, Lewicki M, Lemańska Ż, Rzymski P. When science goes viral: The research response during three months of the COVID-19 outbreak. Biomed Pharmacother 2020 Sep;129:110451 [FREE Full text] [doi: 10.1016/j.biopha.2020.110451] [Medline: 32603887 ]

23. De Felice F, Polimeni A. Coronavirus Disease (COVID-19): A Machine Learning Bibliometric Analysis. In Vivo 2020 Jun;34(3 Suppl):1613-1617. [doi: 10.21873/invivo.11951] [Medline: 32503819]

24. Mao X, Guo L, Fu P, Xiang C. The status and trends of coronavirus research: A global bibliometric and visualized analysis. Medicine (Baltimore) 2020 May 29;99(22):e20137 [FREE Full text] [Medline: $\underline{\text { 32481379] }}$

25. Chahrour M, Assi S, Bejjani M, Nasrallah A, Salhab H, Fares M, et al. A Bibliometric Analysis of COVID-19 Research Activity: A Call for Increased Output. Cureus 2020 Mar 21;12(3):e7357 [FREE Full text] [doi: 10.7759/cureus.7357] [Medline: 32328369]

26. Lou J, Tian S, Niu S, Kang X, Lian H, Zhang L, et al. Coronavirus disease 2019: a bibliometric analysis and review. Eur Rev Med Pharmacol Sci 2020 Mar;24(6):3411-3421 [FREE Full text] [doi: 10.26355/eurrev_202003_20712] [Medline: $\underline{32271460}]$

27. Warin T. Global Research on Coronaviruses: An R Package. J Med Internet Res 2020 Aug 11;22(8):e19615 [FREE Full text] [doi: 10.2196/19615] [Medline: 32730218]

28. Fidahic M, Nujic D, Runjic R, Civljak M, Markotic F, Lovric Makaric Z, et al. Research methodology and characteristics of journal articles with original data, preprint articles and registered clinical trial protocols about COVID-19. BMC Med Res Methodol 2020 Jun 22;20(1):161 [FREE Full text] [doi: 10.1186/s12874-020-01047-2] [Medline: 32571302]

29. Serlachius A, Badawy SM, Thabrew H. Psychosocial Challenges and Opportunities for Youth With Chronic Health Conditions During the COVID-19 Pandemic. JMIR Pediatr Parent 2020 Oct 12;3(2):e23057 [FREE Full text] [doi: 10.2196/23057] [Medline: 33001834$]$

30. Badawy SM, Radovic A. Digital Approaches to Remote Pediatric Health Care Delivery During the COVID-19 Pandemic: Existing Evidence and a Call for Further Research. JMIR Pediatr Parent 2020 Jun 25;3(1):e20049 [FREE Full text] [doi: 10.2196/20049] [Medline: 32540841]

31. Brown A, Horton R. A planetary health perspective on COVID-19: a call for papers. The Lancet 2020 Apr;395(10230):1099. [doi: 10.1016/s0140-6736(20)30742-x]

32. Ioannidis J. Coronavirus disease 2019: The harms of exaggerated information and non-evidence-based measures. Eur J Clin Invest 2020 Apr;50(4):e13222 [FREE Full text] [doi: 10.1111/eci.13222] [Medline: 32191341] 


\section{Abbreviations}

MCP: multiple-country publication

SCP: single-country publication

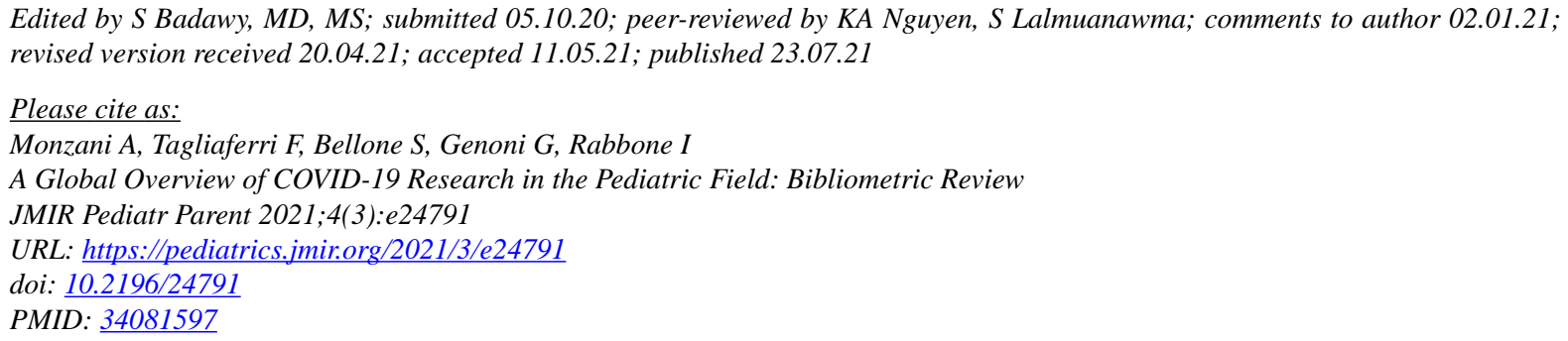

CAlice Monzani, Francesco Tagliaferri, Simonetta Bellone, Giulia Genoni, Ivana Rabbone. Originally published in JMIR Pediatrics and Parenting (https://pediatrics.jmir.org), 23.07.2021. This is an open-access article distributed under the terms of the Creative Commons Attribution License (https://creativecommons.org/licenses/by/4.0/), which permits unrestricted use, distribution, and reproduction in any medium, provided the original work, first published in JMIR Pediatrics and Parenting, is properly cited. The complete bibliographic information, a link to the original publication on https://pediatrics.jmir.org, as well as this copyright and license information must be included. 